Dept. of Animal Production,

Fac. of Agriculture, Assiut Univ.,

Head of Dept. Prof. Dr. M.N. Makled

\title{
EFFECT OF LONG-TERM TREATMENT OF INSULIN ON GROWTH PERFORMANCE, LIPID METABOLISM AND ELECTROLYTE IN OREOCHROMIS NILOTICUS
}

(With 4 Tables and 18 Figures)

By

\author{
M.B. AL-SALAHY* and S.Y. HUSSEIN**
}

(Received at 27/7/1995)

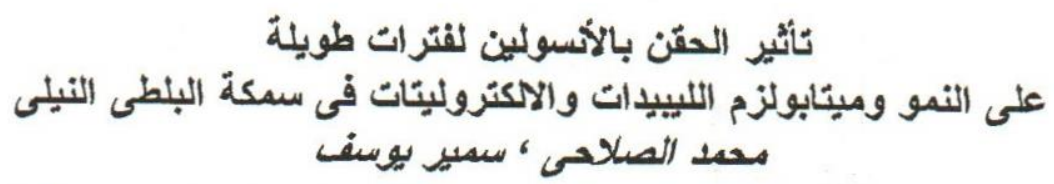

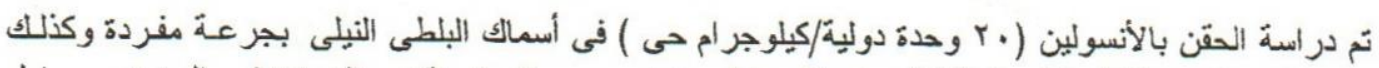

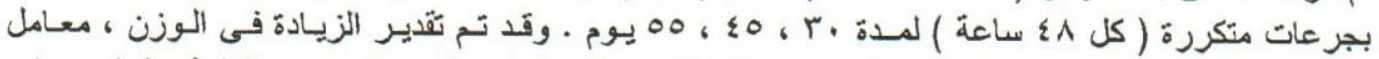

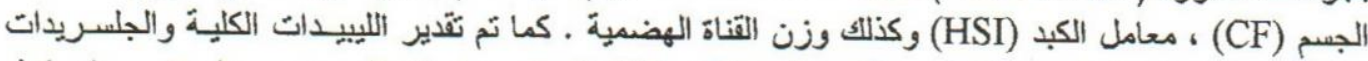

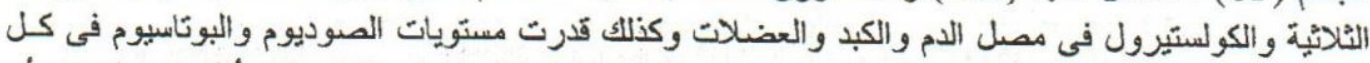

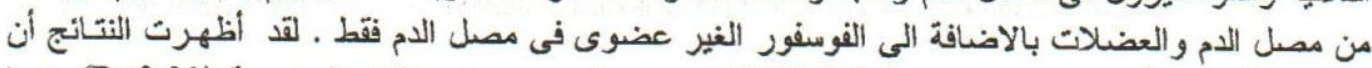

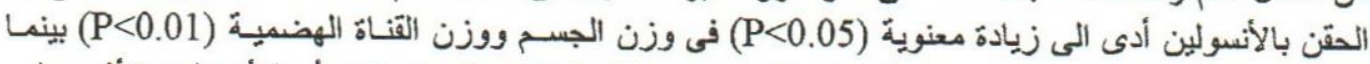

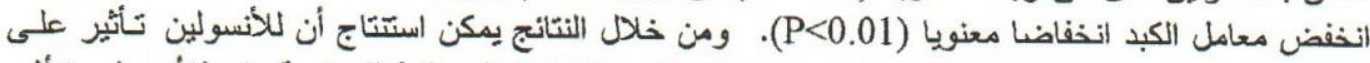

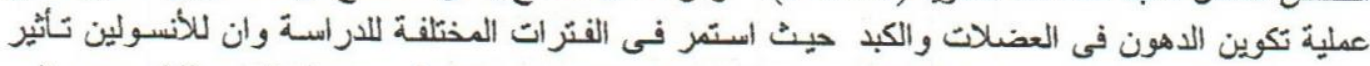

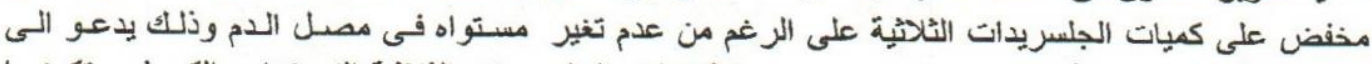

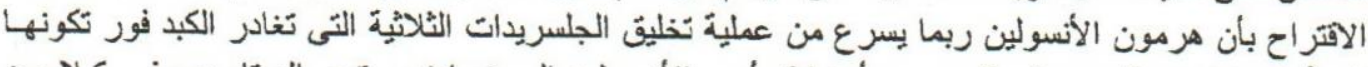

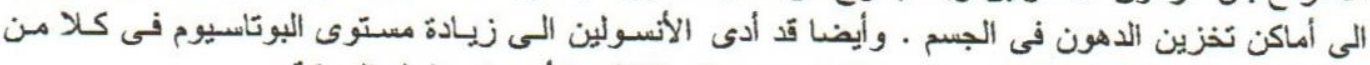

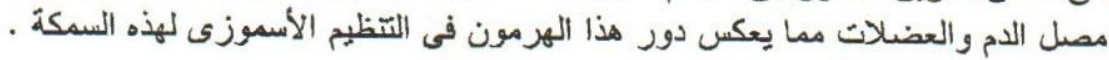

\section{SUMMARY}

Forty Nile fish, Oreochromis niloticus were injected with insulin (20 IU/Kg body weight) for different periods. Single dose for $24 \mathrm{~h}$ and repeated doses (dose every $48 \mathrm{~h}$ for 30,45 and 55 days) were used in this experiment. Body gain, condition factor (Cf), hepatosomatic index (HSI) and gut weight were calculated. Levels of total lipids, triglycerides and cholesterol were determined in serum, liver and myotomal muscle.

\footnotetext{
*: Zoology Dept., Fac. Sci., Assiut University.

**: Animal Production Dept., Fac. of Agriculture, Assiut University.
} 


\section{AL-SALAHY \& HUSSEIN}

Also, sodium and potassium levels were estimated in both serum and muscle but inorganic phosphorus was determined only in serum. Insulin injection increased significantly body gain $(\mathrm{P}<0.05)$ and gut weight $(\mathrm{P}<0.01)$. While hepatosomatic index was significantly decreased $(\mathrm{P}<0.01)$ in insulin treated group at 30 and 45 days of the experimental periods. The prolonged administration of insulin in Oreochromis niloticus showed a continued effect on the stimulation of lipogenic in the myotomal muscle as well as in the liver triglycerides synthesis. The lowering effect of insulin on liver content of triglycerides but not in the serum. let to suggest that insulin might promote the triglyceride synthesis in liver to be removed as rapidly as synthesized to lipid stores in the body. The increasing effect of insulin on serum and muscle potassium level probably reflect role of such hormone in osmoregulation in this fish.

Kaywords: Long-term treatment, insulin and Oreochromis niloticus.

\section{INTRODUCTION}

Many investigators have studied the metabolic effects of insulin in lower vertebrates, particularly fish (INUI and YOKOTE, 1975, LEWANDER et al., 1976; OTTOLENGHI et al., 1982, FOSTER and MOON, 1989 and $A L$ SALAHY et al., 1994). The majority of these studies were carried out as shortterm treatment and have been focused on either carbohydrate metabolism or amino acid incorporation into tissues with little attention on the lipid metabolism.

On studying the glucose tolerance test in many species of fish, many workers concluded that fish naturally suffer from insulin deficiency (FURUICHI and YONE, 1981, 1982). These teleost fish utilize carbohydrate poorly, depending primarly on protein and lipid for energy production (FURUICHI et al., 1971; NAGAI and IKEDA, 1972; BRETT and
GROVES, 1979 and WALTON and COWEY, 1982). Furthermore, the short length of the first proximal tubule in the kidney of most fresh-water teleosts was responsible for incomplete glucose reabsorption from the filtrate (HICKMAN and TRUPM, 1969). Thus, insulin administration into fish may enhance dietary carbohydrate utilization as a source of energy instead of dietary protein and lipids. So, LUDWIG et al. (1977) recorded $22 \%$ body weight increase in coho salmon after insulin injection (3.2 IU/Kg body weight twice weekly).

Little attention was paid to study the metabolic effect of the prolonged adminstration of insulin in fish, previously, the authors investigated the effect of long-term injection of insulin on carbohydrate and free amino acids metabolism in Oreochramis niloticus (AL-SALAHY $\underline{\text { et }}$ al., 1994). They found that the effect of repeated doses $(20 \mathrm{IU} / \mathrm{Kg}$ every $48 \mathrm{~h}$ for 30,45 and 55 days) of insulin did not 


\section{LONG-TERM TREATMENT, INSULIN \& OREOCHROMIS NILOTICUS}

continue at the same level on carbohydrate and free amino acids. Similary, the effect of insulin on glycemic level was not continued by the same extent in trout during long-term treatment (ABLETT $\underline{\text { et }}$ al., 1981). This finding let the authors to suggest an adaptation response was occurred. However, ABLETT et al. (1981) concluded that the effect of prolonged administration of insulin in trout directed toward the lipogenic and proteogenic pathway.

Furthermore, there was a few experiments concerning insulin role on electrolytes in fish. Since DE-FRONZO et al. (1980) decleared that insulin stimulate the muscle uptake of potassium, on the other hand, LEWANDER $\underline{\text { et }}$ al. (1976) did not show any change in plasma sodium and potasium level in Anguilla anguilla. In Clarias lazera $A L$ $S A L A H Y$ (1990) recorded an increase in plasma inorganic phosphorus after insulin treatment.

The objective of this investigation was to examine the effect of prolonged administration of insulin (20 IU/Kg body weight) on growth performance, lipid metabolism and electrolytes in Nile fish, Oreochromis niloticus.

\section{MATERLALS and METHODS}

\section{Materials:}

\section{A total number of 40 adult}

Oreochromis niloticus were collected from the River Nile at Assiut region. The average body weight and length were $70 \pm 1.1 \mathrm{~g}$ and $16 \pm 0.9$ $\mathrm{cm}$.respectively. The fish were immediately transported after catching to special aquaria in the laboratory (100 liter capacity) filled with aerated fresh water. The water temperature was adjusted thermostatically at $22 \pm 0.05^{\circ} \mathrm{C}$. The fish were acclimatized to the laboratory conditions for 2 weeks before the beginning of experiment. Twenty fish were injected intraperitoneally with normal saline solution $(0.65 \%)$ which represented the control and divided into 4 groups, 5 animals each. Fish of the first group were sacrificed $24 \mathrm{hr}$ after saline injection. Individuals of the second, third and fourth group were exposed to repeated injections of saline for 30,45 and 55 days (dose every $48 \mathrm{~h}$ ).

The other 20 fish were injected intraperitoneally with either single or repeated mammalian insulin doses (Lante insulin) and were divided into 4 groups, 5 animals each. The animals of the first group were injected with single dose of insulin (20 IU/ $\mathrm{Kg}$ body weight) and were sacrificed $24 \mathrm{~h}$ after treatment. The animals of the second, third and fourth group were injected with repeated doses (dose $20 \mathrm{IU} / \mathrm{Kg}$ body weight every $48 \mathrm{~h}$ ) for 30,45 and 55 days respectively. The fish were fed normal diet twice daily at $3 \%$ of mean body weight. After the final dose of insulin injection, all fish were fasted for $24 \mathrm{~h}$ before sacrifice.

The individual fish body weight, body length was recorded weekly. Liver and 


\section{AL-SALAHY \& HUSSEIN}

gut weight were recorded at $24 \mathrm{~h}$ and 30,45 and 55 days of study. Then body gain, condition factor (body wt./Length $\left.{ }^{3} \mathrm{X} 100\right)$ and hepatosomatic index (liver wt./body wt.X100) were calculated.

Samples of blood serum, liver and lateral myotomal musculature (below the dorsal fin) were taken. Liver and muscle samples were dried at $60^{\circ} \mathrm{C}$ till constant weight has been obtained, then followed by grinding. Samples were kept at $-20^{\circ} \mathrm{C}$ until biochemical analysis.

\section{Methods:}

A- Total serum lipids were estimated by kit ( bioMerieux, France). The estimation of total lipids in liver and muscle was made by the same kits after the extraction of lipid by chloroform; methanol mixture $(2: 1)$ as described by FOLCH $\underline{\text { et }} \underline{\mathrm{al}}$. (1957).

B- Tissue cholesterol and triglycerides were determined after extraction of total lipid by the method of FOLCH et al. (1957). Determination of triglycerides and cholesterol, in serum, liver and muscle lipid extracts was carried out colormitrically by means of kits ( bioMerieux ,France).

C- Sodium and potassium levels were determined in serum and in aquaeous muscle extract by flame photometer (Corning 400). Serum inorganic phosphorus was estimated by using bioMerieux kits.

\section{RESULTS}

\section{a) Growth performance:}

Insulin injection resulted in significant increase $(\mathrm{P}<0.05)$ in fish body weight and net weight. Average body gain was 0.74 and $1.43 \mathrm{~g} /$ fish in control and insulin treated fish respectively (Fig. 1). Also, the length and condition factor (Cf) increased in the treated group of 55 days but this increase was not significant (Fig. 2). While, the hepatosomatic index (HSI) was significantly decreased $(\mathrm{P}<0.01)$ at period of 30 and 45 days (Fig. 3). The gut weight was significantly heavier $(\mathrm{P}<0.01)$ in insulin treated group (Fig. 4).

\section{b) Lipid metabolism:}

In single dose group, insulin injection led to hypolipidemia $(\mathrm{P}<0.01)$ and insignificant change in muscle lipids. In repeated-dose groups the lipogenic pathway was significantly $(\mathrm{P}<0.05)$ increase in myotomal muscles, which represent the considerable mass in fish, in spite of its unchanged level in both serum and liver (Tables 1, 2 and 3 and Figs. 5-13). Triglyceride levels decreased significantly $(\mathrm{P}<0.01)$ in liver only in both single and repeated-dose groups (Table 2), serum riglycerides/total lipids ratio (\%) was significantly $(\mathrm{P}<0.01)$ increased in single dosegroup, while it was significantly $(\mathrm{P}<0.01)$ decreased in liver in both single and repeated-dose groups (Tables 1 and 2). Cholesterol level was influenced 


\section{LONG-TERM TREATMENT, INSULIN \& OREOCHROMIS NILOTICUS}

only by single dose injection in both serum and liver,but in oppesit direction where it was significantly decreased $(\mathrm{P}<0.01)$ in the former and increased in the later. In general, the action of insulin on lipids, was continued for 55 days (Time of the experiment) in Oreochromis niloticus. In contrary, the effect of insulin treatment on carbohydrates and free amino acids did not continue for 55 days at the same conditions in the same fish (Al-Salahy et al., 1994).

\section{c) Electrolytes:}

Table (4) and figs. from 14 to 18 showed significant $(\mathrm{P}<0.05)$ increase in potassium $\left(\mathrm{K}^{+}\right)$level in serum and muscle in injected group with insulin for 55 days. While the changes in sodium $\left(\mathrm{Na}^{+}\right)$level of serum and muscle as well as in serum organic phosphorus $(\mathrm{P})$ was not significant.

\section{DISCUSSION}

In the present study, injection of insulin caused a significant increase $(\mathrm{P}<0.05)$ in body gain of fish (Fig. 1). Such effect was mainly due to the anabolic effect of insulin. Ablett et al.,(1981) stated that insulin has growth effect in rainbow trout after 56 days treatment. Moreover, they recorded an increase in muscle protein and lipid contents. Indeed, insulin increased both number and size of cells. Insulin promotes the muscle uptake of serum amino acids in the same fish at the same insulin level (AL-SALAHY et al., 1994). Also, from the present results it can be concluded that the increase in body gain may be due to that insulin stimulates the protein and lipid synthesis in muscles of the fish (Table 3).

The fish length and condition factor were not significantly affected by insulin injection. This may be due to as previously mentioned that insulin has mainly anabolic effect. Insulin injections lower the hepatosomatic index (HSI) significantly $(\mathrm{P}<0.01)$ after 30 and 45 days. This result may be due to that insulin decreases significantly the accumulation of lipids in liver in group at $24 \mathrm{~h}$, and 30,45 and 55 days after insulin injection (Table 2). These results are agree with the findings of LEWANDER et $\underline{\mathrm{al}}$., (1976) on Anguilla anguilla injected with a high dose $(100 \mathrm{IU} / \mathrm{kg})$. In contrary, low insulin dose increased the HSI in rainbow trout injected with 0.5 IU insulin every $48 \mathrm{~h}$ for 56 days (ABLETT, et al., 1981). However, it could be attributed this difference in the results to fish species and insulin dose The gut weight increased significantly $(\mathrm{P}<0.01)$ in the treated group than the control one after 30 and 45 days of experimental period. This result is supported by SAKATA et al. (1980) who stated that insulin administration in creased the weight of digestive tract and mitotic index of rumen in sheep.

Insulin often induces hypolipidemic state in mammals (GRODSKY, 1983). In fish, the situation is somewhat differ, 
where there were variable effects of the exogenous insulin on plasma lipid contents while the level of plasma lipids, triglycerids and cholesterol was not affected few hours to few days after single dose $(100 \mathrm{IU} / \mathrm{Kg})$ of insulin treatment in Anguilla anguilla (LEWANDER ET AL., 1976). and in Opsanus tau (TASHIMA and Cahill, 1968). In contrary, single dose of insulin $(10 \mathrm{IU} / \mathrm{Kg})$ led to hypolipidemia $72 \mathrm{~h}$ after treatment in Clarias lazera (AL-SALAHY, 1990). He recorded hypotriglyceridemia 24, 18 and $48 \mathrm{~h}$ after treatment. Similarly, YANNI (1967) recorded $85.3 \%$ decrease in plasma total lipids $24 \mathrm{~h}$ after single insulin injection (dose $10 \mathrm{IU} / \mathrm{kg}$ ) in Clarias lazera. The present work showed that the single dose of insulin significantly $(\mathrm{P}<0.01)$ lowered serum levels of total lipids and cholesterol, but it did not affect the serum level of triglycerides. The great decrease in serum total lipids was concomitant with the unchanged serum triglyceride levels and the increase in the triglycerides/ total lipids ratio let to suggest that serum fatty acids level might be the major lipid fraction of insulin action. This concept was in harmony with that reported in Carassius auratus by MINICK and CHAVIN (1972).

Data obtained herein, showed that insulin did not affect the serum levels of total lipids, triglycerides and cholesterol in the repeated doses of all periods. However, in previous study, repeated doses of insulin, under the same conditions, significantly decreased serum levels of glucose and free amino acids in Oreochromis niloticus after treatment for 30 and 45 days (AL-SALAHY et al. 1994). Repeated doses for short-term treatment $(10 \mathrm{IU} / \mathrm{Kg} / 24 \mathrm{~h}$ for $72 \mathrm{~h})$ in Clarias lazera led to $86.0 \%$ decrease in plasma total lipids (YANNI, 1967).

In the present study, single dose of insulin led to marked decrease in the liver contents of total lipids and triglycerides. In Clarias lazera, liver total lipids were not affected, few hours to 3 days, after single injection of insulin $10 \mathrm{IU} / \mathrm{Kg}$ (AL-SALAHY, 1990). Also, liver total lipid content did not show any significant change in Anguilla japonica injected by single dose ( $5 \mathrm{IU} / \mathrm{Kg})$, for $5 \mathrm{~h}$ or by repeated doses $(5 \mathrm{IU} / \mathrm{Kg} / 12 \mathrm{~h})$ for $48 \mathrm{~h}$ (INUI and YOKOTE, 1975).

The data showed also that repeated doses for 30,45 and 55 days decreased the liver triglyeride content. Consequently, significant decrease $(\mathrm{P}<0.01)$ in triglycerides/total lipids ratio in liver was seen in the same periods of treatment. In mammals, insulin injection increased the rate of lipogenesis from glucose and the synthesis of triglycerides in the liver and removed as rapidly as synthesized (MAYES, 1983). In trout, Salmo gairdneri, ABLETT et al. (1981) recorded a significant decrease in liver lipids after 56 days of repeated doses of insulin $(0.5 \mathrm{IU} / \mathrm{Kg}$ every $48 \mathrm{~h})$.

In the present study, the decreasing effect of single dose of insulin on the serum cholesterol level was accompanied by marked increase in liver cholesterol 
level and insignificant change in its level in muscle. Such result suggests that the short-term treatment of insulin, in Oreochromis niloticus, might enhance the liver uptake of serum cholesterol.

Data obtained herein showed that insulin significantly $(\mathrm{P}<0.05)$ increases the muscle total lipid content in repeated doses of 30,45 and 55 days in spite of unchanged its level in both serum and liver in that periods. In previous study, $A L-S A L A H Y$ et. al.,1994 showed that repeated doses of insulin injection into Oreochromis niloticus, under the same conditions of this work, induced hypoglycemia accompanied by unchanged glycogen levels in liver and muscle after 30 and 45 days of treatment. Also they recorded a reduced serum free amino acids accompanied by hypoglycemia. Moreover, insulin treatments increase the cellular uptake of free fatty acids resulting in stimulation of lipogenesis (GOLDFINE, 1977).

The elevated muscle level of potassium in treated group of 55 days (Fig. 17) may be due to that insulin stimulate the muscle uptake of potassium. This concept based on the finding of $D E$ FRONZO et al. (1980) that insulin mediated the potassium uptake by muscle in mammals. Serum sodium level decreased in treated fish but this decrease was not significant (Fig.14). In turn, muscle sodium level showed insignificant increase at the same periods of treatment (Fig.16 ). Similarly, insignifi- cant changes in plasma sodium level is Anguilla anguilla treated by single dose of insulin (LEWANDER et al., 1976) Serum phosphorus level did not shov any significant change(Fig.18). In Clarias lazera, AL-SALAHY (1990) showed an increase in plasma inorganic phosphorus level 24 and $72 \mathrm{~h}$ after treatment.

Accordingly, it can be suggestes tha insulin injection into Oreochromis niloticus, may enhance muscle lipo genesis from the major precursor; fre fatty acids as well as glucose and fre amino acids. Similarly, ABLETT et $\underline{a l}$ (1981) reported an increase in lipid content of skeletal muscle of rainbov trout (Salmo gairdneri) following the re peated insulin injections for 56 days. Moreover, insulin increased radioactivi glycine into lipid and protein in teleos fish (THORPE and INCE, 1974 and INCE and THORPE, 1976). On the other hand, ASTER (1981) found that the major precursor of lipogenesis in fisl Anguilla rostrata was the dietary lipic content. Insulin $(10 \mathrm{IU} / \mathrm{Kg})$ promoted lipogenesis in the red muscle of Claria. lazera $18 \mathrm{~h}$ after treatment. In the pre sent study, the effect of repeated dose of insulin on lipid metabolism was con tinued for 55 days. On contrary, $A L$ $S A L A H Y$ et al. (1994) found that insulin effect on carbohydrate or free amino acid levels was not continued for 55 days and they were suggested that adaptation response to such hormone 
was occurred. This result is in harmony with that reported in trout by $A B L E T T \underline{\text { et }}$ al., (1981).

In conclusion, long-term insulin injection increased fish body weight due to the anabolic effect of insulin on protein synthesis and lipogenesis in skeletal muscle of fish. However, from economi- cal point of view single dose is recommended. In liver, insulin might promote the synthesis of triglycerides to be removed as rapidly as synthesized to lipid stores in the body. Also, the insulin effect on electrolytes may reflect the regulatory role of this hormone on osmoregulation in this fish.

\section{REFERENCES}

Ablett, R.F.; Sinnhuber, R.O.; Homes, R.M. and Selivonchick, D.P. (1981): The effect of prolonged administration of bovine insulin in rainbow trout, Salmo gairdneri. Gen. Comp. Endocrinol. 43, 211-217.

Al-Salahy, M.B. (1990): Some metabolic effects of insulin and alloxan in the Nile fish, Clarias lazera, $\mathrm{Ph} . \mathrm{D}$. Thesis, Assiut University.

Al-Salahy, M.B.; Hassanein, A.A.; Ahmed, Sh.M. and Hussein, S.Y. (1994): Metabolic effect of insulin on carbohydrate and free amino acid contents in the Nile fish, Oreochromis niloticus. Bull. Fac. Sci., Assiut University, 23 (2-E), p. 15-66.

Aster, P.L. (1981): Fatty acid synthesis in the American eel, Anguilla rostrata: tissue sites, reducing equivalents and carbon source (S). Ph.D. Thesis, Univ., Ottawa, Ottawa, Ont. $111 \mathrm{P}$.

Brett, J.R. and Groves, T.D.D. (1979): Physiological energetics. IN "Fish physiology" (W.S. Hoar, D.J. Randall and J.R. Brett, eds.). Vol. 8, PP. 279-352, Academic press, New York.

De-Fronzo, R.; Hendler, R. and Christensen, N.J. (1980): Stimulation of counterregulatory hormonal responses in diabetic man by a fall in glucose concentration. Diabetes, 29: 125.

Folch, J.; Lea, M.M. and Stanely, G.H.S. (1957): A simple method for the isolation and purification of total lipids from animal tissues. J. Biol. Chem. 226, 497509.

Foster, G.D. and Moon, T.W. (1989): Insulin and the regulation of glycogen metabolism and gluconeogenesis in American eel hepatocytes. Gen. Comp. Endocrinol. 73, 374-381.

Furuichi, M. and Yone, Y. (1981): Change of blood sugar and plasma insulin levels of fishes in glucose tolerance test. Bull. Japan. Soc. Sci. Fish. 47(6), 761-764. Furuichi, M. and Yone, Y. (1982): Effect of insulin on blood sugar levels of fishes. Bull. Japan. Soc. Sci. Fish. 48(9), 1289-1291.

Furuichi, M.; Shitanda, K. and Yone, Y. (1971): Studies on nutrition of red sea bream-

V Appropriate supply of dietary carbohydrate. Fish. Res. Lab., Kyuchu Univ., 1, 91-100. 


\section{LONG-TERM TREATMENT, INSULIN \& OREOCHROMIS NILOTICUS}

Goldfine, I.D. (1977): Does insulin need a second messenger? Diabetes 26, 148-155. Grodsky, G.M. (1983): Chemistry and function of the hormones (III pancreas and gastrointestinal tract). In "Harper's review of biochemistry" (D.W. Martin, P.A. Mayes and V.W. Rodwell, eds). 33, PP. 511-522, Middle east edition, Beirut, Lebanon.

Hickman, C.P. and Trump, B.F. (1969): The kidney. In "Fish physiology" (W.S. Hoar and D.J. Randall and J.R. Brett, eds.). Vol. 1, PP. 91-239. Acadamic Press, New York.

Ince, B.W. and Thorpe, A. (1976): The "In vivo" metabolism of ${ }^{14} \mathrm{C}$-glycine in insulin treated Northern pike (Esox lucius L.). Gen. Comp. Endocrinol, 28, 481-486.

Inui, Y. and Yokote, M. (1975): Gluconeogenesis in the eel-III effects of mammalian insulin on the carbohydrate metabolism of the eel. Bull. Japan. Soc. Sci. Fish. 41(9): 965-972.

Lewander, K.; Dave, G.; Johansson-sobeck, M.L.; Larsson, A. and Lidman, U. (1976): Metabolic effects of insulin in the European eel, Anguilla anguilla. Gen. Comp. Endocrinol. 29, 455-467.

Ludwig, B.; Higgs, O.A.; Fogerlund, U.H.M. and McBride, J.R. (1977): A preliminary study of insulin participation in the growth regulation of coho salmon (O.Kisutch). Canad. J. Zool. 55, 1756-1758.

Mays, P.A. (1983): Regulation of carbohydrate and lipid metabolism. In "Harper's review of biochemistry (D.W., Martin, P.M. Mayes and V.R. Rodwell, eds.). 19, PP. 248-264. Middle east edition, Beirut, Lebanon.

Minick, C.M. and Chavin, W. (1972): Effect of alloxan, streptozotocin or Dmannoheplulose upon serum free fatty acids and serum glucose levels in goldfish, Carassius auratus. Comp. Biochem. Physiol. 42, 367-376.

Nagai, M. and Ikeda, S. (1972): Carbohydrate metabolism in fish. III. Effect of dietary composition on metabolism of glucose $(\mathrm{U}-14 \mathrm{C})$ and glutamate $\left(\mathrm{U}-{ }^{14} \mathrm{C}\right)$. Nippon Suissan Gakkaishi 38, 137-143.

Ottolenghi, C.; Puviani, A.C.; Baruffaldi, A. and Bringhenti, L. (1982): "In vivo" Effect of insulin on carbohydrate metabolism of catfish, Ictalurus melas. Comp. Biochem. Physiol. 72, 35-41.

Sakata, T.K.; HikosaKa, Y. Shiomura and H. Tamate (1980): Stimulatory effect of insulin on ruminal epithelium cell mitosis in adult sheep. Br. J. Nutr. 44: 325 331.

Tashima, L. and Cahill, G.F. (1968): Effects of insulin in the toad fish Opasanus tau. Gen. Comp. Endocrinol. 11, 262-271.

Thorpe, A and Ince, B.W. (1974): The effects of pancreatic hormones, catecholamines and glucose loading on blood metabolites in the Northern Pike (Esox lucius L.). Gen. Comp. Endocrinol., 23, 29-44. 


\section{AL-SALAHY \& HUSSEIN}

Walton, M.J. and Cowey, C.B. (1982): Aspects of intermediary metabolism in salmonid fish. Comp. Biochem. Physiol., 73, 59-69.

Yanni, M. (1967): Effect of insulin on carbohydrate, water and fat contents of the tissues of Clarias lazera. Proc. Zool. U.A.R., I, 130-140.

Table (1): Effect of insulin (20 IU/Kg body weight) on serum total lipids, triglycerdes, triglycerides/total lipid ratio (\%) and cholesterol of Oreochromis niloticus

\begin{tabular}{|c|c|c|c|c|c|c|c|c|}
\hline & \multirow{2}{*}{\multicolumn{2}{|c|}{$\begin{array}{c}\text { Single } \\
24 \mathrm{~h} \\
\end{array}$}} & \multicolumn{6}{|c|}{ Repeated doses } \\
\hline & & & \multicolumn{2}{|c|}{30 dyas } & \multicolumn{2}{|c|}{45 days } & \multicolumn{2}{|c|}{55 days } \\
\hline & C & $\mathbf{T}$ & $\mathrm{C}$ & $\mathbf{T}$ & C & $\mathbf{T}$ & $\mathrm{C}$ & $T$ \\
\hline Total lipids (mg/dl) & $\begin{array}{l}446 \\
\pm 17.6\end{array}$ & $\begin{array}{l}283^{* *} \\
\pm 36.7\end{array}$ & $\begin{array}{l}463 \\
\pm 98.4\end{array}$ & $\begin{array}{l}336 \\
\pm 48.4\end{array}$ & $\begin{array}{l}426 \\
\pm 75.4\end{array}$ & $\begin{array}{l}330 \\
\pm 71.0\end{array}$ & $\begin{array}{l}420 \\
\pm 15.2\end{array}$ & $\begin{array}{l}450 \\
\pm 23.1\end{array}$ \\
\hline Triglycerides (mg/dl) & $\begin{array}{l}169 \\
\pm 6.6\end{array}$ & $\begin{array}{l}166 \\
\pm 11.1\end{array}$ & $\begin{array}{l}170 \\
\pm 7.9\end{array}$ & $\begin{array}{l}133 \\
\pm 25.6\end{array}$ & $\begin{array}{l}168 \\
\pm 12.1\end{array}$ & $\begin{array}{l}179 \\
\pm 3.0\end{array}$ & $\begin{array}{l}164 \\
\pm 5.2\end{array}$ & $\begin{array}{l}150 \\
\pm 16.5\end{array}$ \\
\hline $\begin{array}{l}\text { Triglycerides / total } \\
\text { lipids ratio (\%) }\end{array}$ & $\begin{array}{l}38 \\
\pm 2.5\end{array}$ & $\begin{array}{l}59 * * \\
\pm 4.4\end{array}$ & $\begin{array}{l}36 \\
\pm 6.2\end{array}$ & $\begin{array}{l}39 \\
\pm 4.1\end{array}$ & $\begin{array}{l}40 \\
\pm 5.4\end{array}$ & $\begin{array}{l}54 \\
\pm 7.7\end{array}$ & $\begin{array}{l}39 \\
\pm 1.6\end{array}$ & $\begin{array}{l}33 \\
\pm 5.4\end{array}$ \\
\hline Cholesterol (mg/dl) & $\begin{array}{l}27.3 \\
\pm 0.9\end{array}$ & $\begin{array}{l}23.3 * * \\
\pm 0.4\end{array}$ & $\begin{array}{l}26.6 \\
\pm 3.4\end{array}$ & $\begin{array}{l}29.6 \\
\pm 2.7\end{array}$ & $\begin{array}{l}23.3 \\
\pm 3.9\end{array}$ & $\begin{array}{l}25.9 \\
\pm 1.9\end{array}$ & $\begin{array}{l}21.5 \\
\pm 2.7\end{array}$ & $\begin{array}{l}23.5 \\
\pm 3.5\end{array}$ \\
\hline
\end{tabular}

Table (2): Effect of insulin (20 IU/Kg body weight) on liver contents of total lipids, triglycerdes, triglycerides/total lipid ratio (\%) and cholesterol in Oreochromis niloticus

\begin{tabular}{|c|c|c|c|c|c|c|c|c|}
\hline \multirow{3}{*}{$\because$} & \multirow{2}{*}{\multicolumn{2}{|c|}{$\frac{\text { Single }}{24 \mathrm{~h}}$}} & \multicolumn{6}{|c|}{ Repeated doses } \\
\hline & & & \multicolumn{2}{|c|}{30 dyas } & \multicolumn{2}{|c|}{45 days } & \multicolumn{2}{|c|}{55 days } \\
\hline & $\mathbf{C}$ & $\mathbf{T}$ & C & $\mathbf{T}$ & $\mathbf{C}$ & $T$ & $\mathrm{C}$ & $\mathbf{T}$ \\
\hline $\begin{array}{l}\text { Total lipids } \\
\text { (mg/g dry wt). }\end{array}$ & $\begin{array}{l}131 \\
\pm 7.9\end{array}$ & $\begin{array}{l}86^{*} \\
\pm 13.6\end{array}$ & $\begin{array}{l}127 \\
\pm 7.1\end{array}$ & $\begin{array}{l}173 \\
\pm 23.6\end{array}$ & $\begin{array}{l}117 \\
\pm 6.5\end{array}$ & $\begin{array}{l}105 \\
\pm 2.3\end{array}$ & $\begin{array}{l}116 \\
\pm 7.0\end{array}$ & $\begin{array}{l}109.7 \\
\pm 10.7\end{array}$ \\
\hline $\begin{array}{l}\text { Triglycerides } \\
\text { (mg/g dry wt.) }\end{array}$ & $\begin{array}{l}59.2 \\
\pm 8.7\end{array}$ & $\begin{array}{l}15.6^{* *} \\
\pm 0.4\end{array}$ & $\begin{array}{l}53.2 \\
\pm 2.6\end{array}$ & $\begin{array}{l}40.5^{*} \\
\pm 3.4\end{array}$ & $\begin{array}{l}55.2 \\
\pm 3.6\end{array}$ & $\begin{array}{l}26.1^{* *} \\
\pm 1.1\end{array}$ & $\begin{array}{l}60.8 \\
\pm 4.5\end{array}$ & $\begin{array}{l}29.2^{*} \\
\pm 7.0\end{array}$ \\
\hline $\begin{array}{l}\text { Triglycerides / total } \\
\text { lipids ratio (\%) }\end{array}$ & $\begin{array}{l}45.2 \\
\pm 7.3\end{array}$ & $\begin{array}{l}18.1^{*} \\
\pm 5.6\end{array}$ & $\begin{array}{l}41.8 \\
\pm 1.8\end{array}$ & $\begin{array}{l}23.6^{* *} \\
\pm 1.4\end{array}$ & $\begin{array}{l}47.1 \\
\pm 4.2\end{array}$ & $\begin{array}{l}24.3^{* *} \\
\pm 2.6\end{array}$ & $\begin{array}{l}52.4 \\
\pm 2.0\end{array}$ & $\begin{array}{l}26.8^{*} \\
\pm 6.7\end{array}$ \\
\hline $\begin{array}{l}\text { Cholesterol } \\
\text { (mg/g dry wt.) }\end{array}$ & $\begin{array}{l}1.25 \\
\pm 0.1\end{array}$ & $\begin{array}{l}3.50^{* *} \\
\pm 0.3\end{array}$ & $\begin{array}{l}1.43 \\
\pm 0.4\end{array}$ & $\begin{array}{l}1.34 \\
\pm 0.3\end{array}$ & $\begin{array}{l}1.36 \\
\pm 0.3\end{array}$ & $\begin{array}{l}1.12 \\
\pm 0.1\end{array}$ & $\begin{array}{l}1.49 \\
\pm 0.6\end{array}$ & $\begin{array}{l}2.06 \\
\pm 0.1\end{array}$ \\
\hline
\end{tabular}

Data represented by mean \pm standard error $\quad \mathrm{C}=$ control,

* : Significant $(\mathrm{P}<0.05) \quad * *$ : Highly significant $(\mathrm{P}<0.01)$

$\mathrm{T}=$ Treated

$\mathrm{n}=5$ fish $/$ treatment 
Table (3): Effect of insulin ( $20 \mathrm{IU} / \mathrm{Kg}$ body weight) on muscle contents of total lipids, triglycerdes and cholesterol of Oreochromis niloticus

\begin{tabular}{|l|c|c|c|c|c|c|c|c|}
\hline \multirow{2}{*}{} & \multicolumn{2}{|c|}{ Single } & \multicolumn{6}{c|}{ Repeated doses } \\
\cline { 2 - 9 } & \multicolumn{2}{|c|}{$\mathbf{2 4}$ h } & \multicolumn{2}{c|}{ 30 dyas } & \multicolumn{2}{|c|}{ 45 days } & \multicolumn{2}{c|}{ 55 days } \\
\cline { 2 - 9 } & $\mathbf{C}$ & $\mathbf{T}$ & $\mathbf{C}$ & $\mathbf{T}$ & $\mathbf{C}$ & $\mathbf{T}$ & $\mathbf{C}$ & T \\
\hline $\begin{array}{l}\text { Total lipids } \\
\text { (mg/g dry wt.) }\end{array}$ & $\begin{array}{l}56.9 \\
\pm 4.6\end{array}$ & $\begin{array}{l}57.2 \\
\pm 12.2\end{array}$ & $\begin{array}{l}63.6 \\
\pm 8.2\end{array}$ & $\begin{array}{l}135.1^{*} \\
\pm 16.5\end{array}$ & $\begin{array}{l}64.5 \\
\pm 4.9\end{array}$ & $\begin{array}{l}93.5^{*} \\
\pm 4.1\end{array}$ & $\begin{array}{l}58.2 \\
\pm 4.8\end{array}$ & $\begin{array}{l}118.6 * \\
\pm 16.9\end{array}$ \\
\hline $\begin{array}{l}\text { Triglycerides } \\
\text { (mg/g dry wt.) }\end{array}$ & $\begin{array}{l}60.3 \\
\pm 2.4\end{array}$ & $\begin{array}{l}53.1 \\
\pm 7.9\end{array}$ & $\begin{array}{l}58.0 \\
\pm 1.8\end{array}$ & $\begin{array}{l}67.6 \\
\pm 4.8\end{array}$ & $\begin{array}{l}62.7 \\
\pm 5.9\end{array}$ & $\begin{array}{l}63.5 \\
\pm 9.3\end{array}$ & $\begin{array}{l}64.9 \\
\pm 8.8\end{array}$ & $\begin{array}{l}54.6 \\
\pm 6.6\end{array}$ \\
\hline $\begin{array}{l}\text { Cholesterol } \\
\text { (mg/g dry wt.) }\end{array}$ & $\begin{array}{l}0.51 \\
\pm 0.02\end{array}$ & $\begin{array}{l}0.63 \\
\pm 0.09\end{array}$ & $\begin{array}{l}0.41 \\
\pm 0.03\end{array}$ & $\begin{array}{l}0.51 \\
\pm 0.05\end{array}$ & $\begin{array}{l}0.50 \\
\pm 0.05\end{array}$ & $\begin{array}{l}0.45 \\
\pm 0.02\end{array}$ & $\begin{array}{l}0.54 \\
\pm 0.03\end{array}$ & $\begin{array}{l}0.55 \\
\pm 0.02\end{array}$ \\
\hline
\end{tabular}

Table (4): Effect of insulin (20 $\mathrm{IU} / \mathrm{Kg}$ body weight) on serum and muscle level of sodium $\left(\mathrm{Na}^{+}\right)$and potasium $\left(\mathrm{K}^{+}\right)$and serum phosphrus $(\mathrm{P})$ level in Oreochromis niloticus

\begin{tabular}{|c|c|c|c|c|c|c|}
\hline & \multicolumn{2}{|c|}{$30 \mathrm{~d}$} & \multicolumn{2}{|c|}{$45 d$} & \multicolumn{2}{|c|}{$55 \mathrm{~d}$} \\
\hline & C & $\mathbf{T}$ & C & $\mathbf{T}$ & C & $\mathbf{T}$ \\
\hline $\begin{array}{l}\text { a: serum } \\
\text { Sodium (mg/dl) }\end{array}$ & $\begin{array}{l}50.75 \\
\pm 6.65\end{array}$ & $\begin{array}{l}30.25 \\
\pm 5.25\end{array}$ & $\begin{array}{l}60.75 \\
\pm 8.9\end{array}$ & $\begin{array}{l}51.00 \\
\pm 2.88\end{array}$ & $\begin{array}{l}56.00 \\
\pm 4.08\end{array}$ & $\begin{array}{l}56.00 \\
\pm 7.07\end{array}$ \\
\hline Potassium (mg/dl) & $\begin{array}{l}1.67 \\
\pm 0.44\end{array}$ & $\begin{array}{l}2.52 \\
\pm 1.22\end{array}$ & $\begin{array}{l}3.20 \\
\pm 0.69\end{array}$ & $\begin{array}{l}2.77 \\
\pm 0.33\end{array}$ & $\begin{array}{l}1.97 \\
\pm 0.31\end{array}$ & $\begin{array}{l}3.40^{*} \\
\pm 0.33\end{array}$ \\
\hline Phosphorus (mg/dl) & $\begin{array}{l}15.0 \\
\pm 2.9\end{array}$ & $\begin{array}{l}11.9 \\
\pm 1.6\end{array}$ & $\begin{array}{l}14.6 \\
\pm 0.4\end{array}$ & $\begin{array}{l}8.2 \\
\pm 2.3\end{array}$ & $\begin{array}{l}14.6 \\
\pm 0.3\end{array}$ & $\begin{array}{l}10.5 \\
\pm 1.5\end{array}$ \\
\hline $\begin{array}{l}\text { b: muscles } \\
\text { Sodium }(\mathrm{mmol} / \mathrm{L})\end{array}$ & $\begin{array}{l}162.8 \\
\pm 4.75\end{array}$ & $\begin{array}{l}174.3 \\
\pm 6.4\end{array}$ & $\begin{array}{l}168.0 \\
\pm 3.15\end{array}$ & $\begin{array}{l}177.1 \\
\pm 6.08\end{array}$ & $\begin{array}{l}194.6 \\
\pm 1.41\end{array}$ & $\begin{array}{l}188.3 \\
\pm 6.08\end{array}$ \\
\hline Potassium (mmol/L) & $\begin{array}{l}6.46 \\
\pm 0.05\end{array}$ & $\begin{array}{l}7.06 \\
\pm 0.38\end{array}$ & $\begin{array}{l}6.8 \\
\pm 0.03\end{array}$ & $\begin{array}{l}7.35 \\
\pm 0.05\end{array}$ & $\begin{array}{l}7.2 \\
\pm 0.05\end{array}$ & $\begin{array}{l}8.1^{*} \\
\pm 0.3\end{array}$ \\
\hline
\end{tabular}

Data represented by mean \pm standard error $\quad \mathrm{C}=$ control, $\mathrm{T}=$ Treated

* : Significant $(\mathrm{P}<0.05) \quad * *$ : Highly significant $(\mathrm{P}<0.01) \quad \mathrm{n}=5$ fish / treatment 

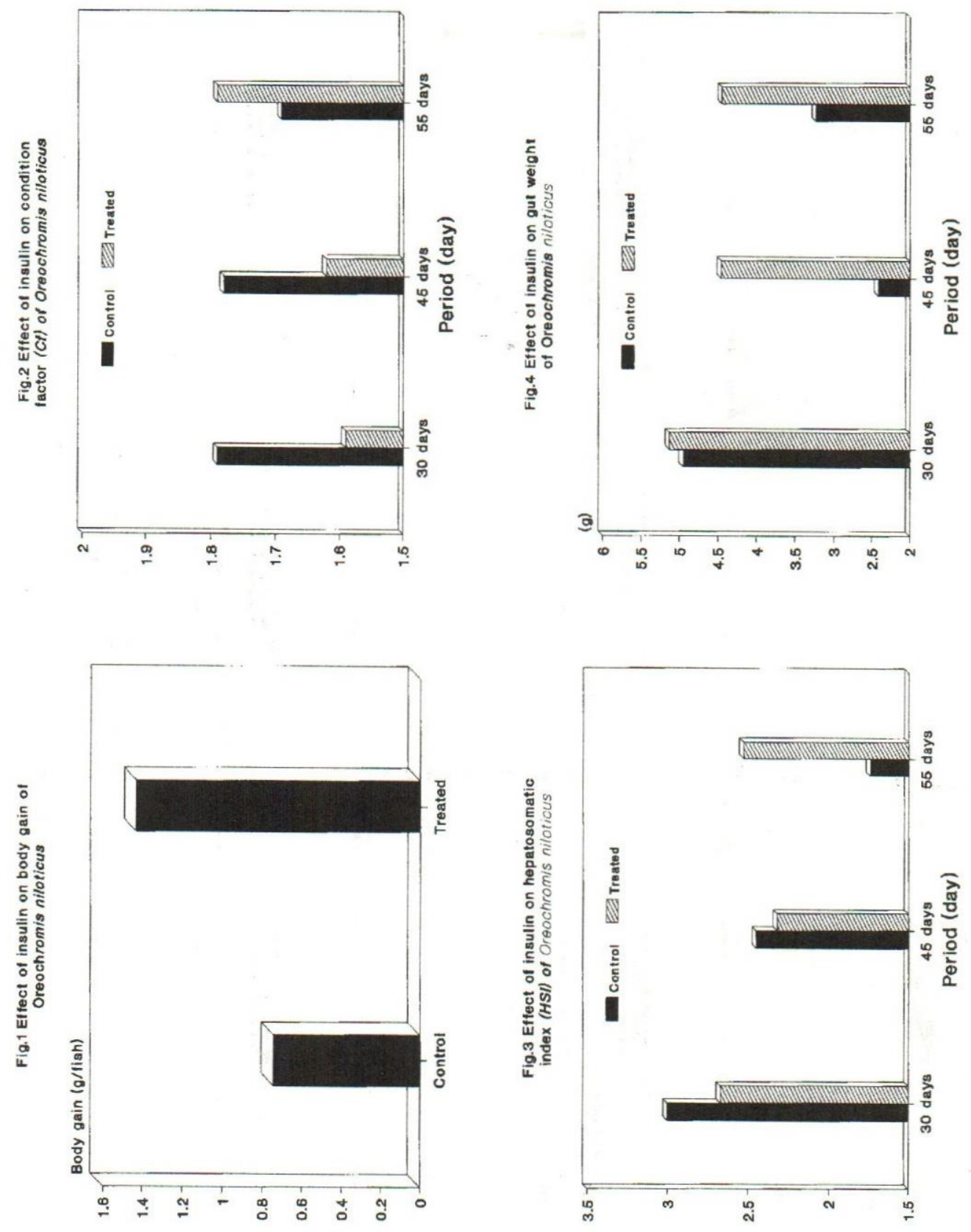
LONG-TERM TREATMENT, INSULIN \& OREOCHROMIS NILOTICUS
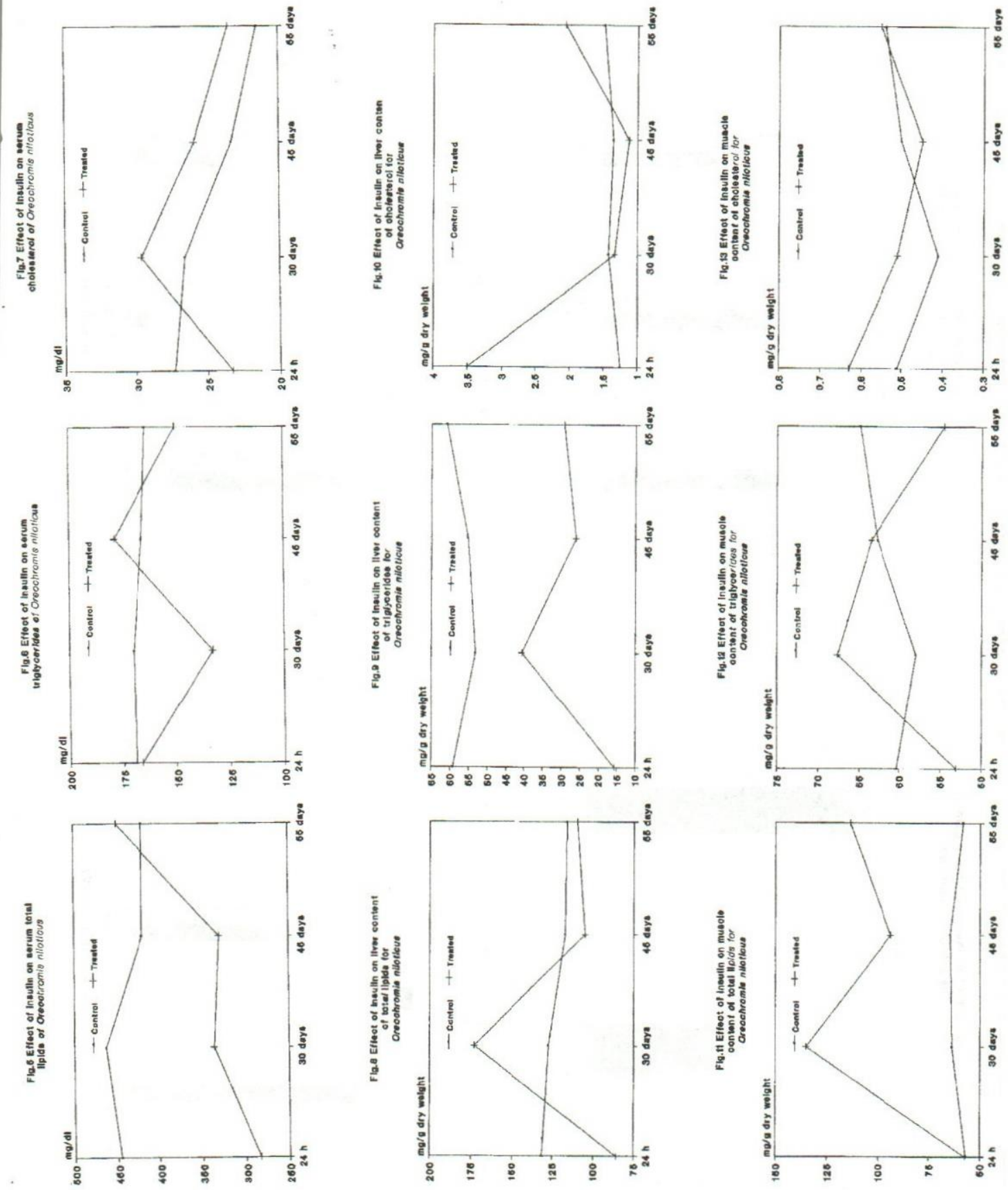
AL-SALAHY \& HUSSEIN
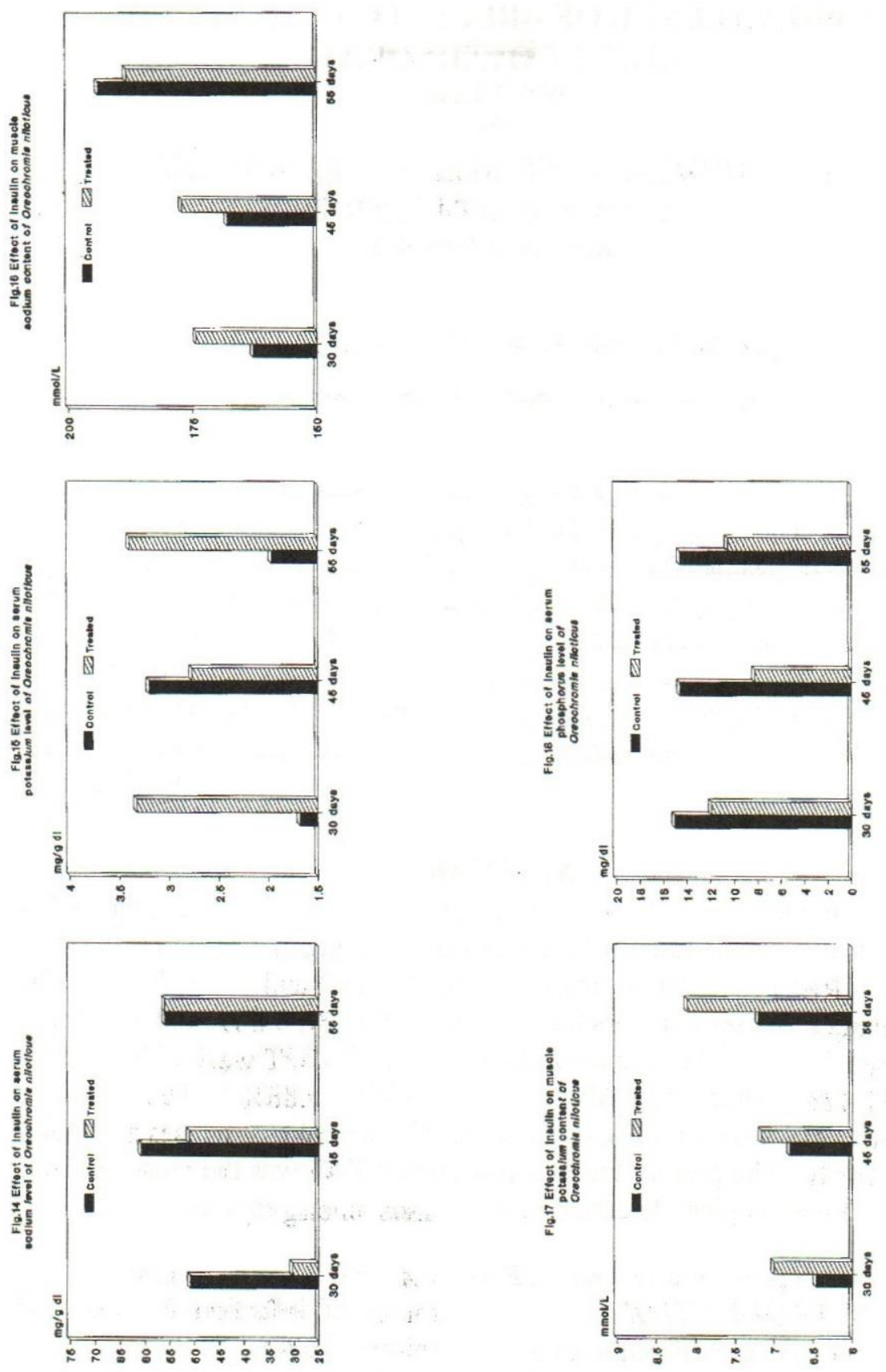